\title{
POTENSI TIGA GENUS BAKTERI DARI TIGA RIZOSFER TANAMAN SEBAGAI AGENSIA PENGENDALI HAYATI PENYAKIT LINCAT
}

\author{
POTENTION OF THREE GENERA OF BACTERIA FROM THREE OF \\ CROP RHIZOSPHERE AS BIOLOGICAL CONTROL AGENT OF THE \\ LINCAT DISEASE
}

\author{
Heru Adi Djatmiko" ${ }^{1)}$, Triwidodo Arwiyanto's) , Bambang Hadisutrisno ${ }^{2)}$, dan Bambang \\ Hendro Sunarminto ${ }^{2)}$ \\ 1) Fakultas Pertanian Unsoed, Purwokerto \\ 2) Fakultas Pertanian UGM, Yogyakarta \\ Jln. dr. Suparno Karangwangkal Purwokerto 53123 \\ heru_adi@yahoo.com
}

\begin{abstract}
Objectives of this research were to characterize three genera of bacteria isolated from three of crop rhizosphere, and to measure the ability of the antagonistic bacteria in suppressing lincat disease caused by Ralstonia solanacearum and Meloidogyne incognita. The research showed that the sixth bacteria were able to utilize some carbon and nitrogen compounds, degrade macromolecules, grew at different temperatures and salt contents, and grew at medium with chitin and pectin. The bacteria isolated from pepper rhizosphere (Pf51, Ba4, Ba22), groundnut (Pf83), and eggplant (S4 dan S7) was included to fluorescent pseudomonads (Pf51 and Pf 83), Bacillus spp. (Ba4 and Ba22), and Streptomyces spp. (S4 and S7). The sixth bacteria having the ability in antagonist. The bacteria isolate having the best ability in suppressing Ralstonia solanacearum and Meloidogyne incognita was Streptomyces spp. (S4). The bacteria isolate having the best ability in suppresssing $R$. solanacearum by antibiosis and the inhibition mechanism by bacteriostatic was $\mathrm{S} 4$.
\end{abstract}

Key words: antagonist bacteria, , lincat disease

\begin{abstract}
ABSTRAK
Tujuan penelitian ini, yaitu untuk mengkarakterisasi tiga genus bakteri yang diisolasi dari tiga rizosfer tanaman dan mengukur kemampuan antagonisnya dalam menekan penyakit lincat yang disebabkan oleh Ralstonia solanacearum and Meloidogyne incognita. Hasil penelitian menunjukkan bahwa Keenam bakteri tersebut mampu memanfaatkan beberapa senyawa karbon dan nitrogen, mendegradasi makromolekul, mampu tumbuh pada berbagai suhu dan kandungan garam, dan tumbuh pada medium yang mengandung kitin dan pektin. Isolat bakteri yang diisolasi dari rizosfer cabai (Pf51, Ba4, Ba22), kacang tanah (Pf83), dan terung (S4 dan S7) termasuk dalam Pseudomonas kelompok fluoresen (Pf51 dan Pf 83), Bacillus spp. (Ba4 dan Ba22), dan Streptomyces spp. (S4 dan S7). Keenam isolat bakteri mempunyai kemampuan antagonis. Isolat bakteri yang paling baik dalam menekan Ralstonia solanacearum dan Meloidogyne incognita adalah Streptomyces spp. (S4). Isolat bakteri yang paling baik menekan Ralstonia solanacearum dengan cara antibiosis dan mekanisme penghambatan secara bakteriostatik adalah S4.
\end{abstract}

Kata kunci: bakteri antagonis, penyakit lincat 


\section{PENDAHULUAN}

Ralstonia solanacearum dan Meloidogyne incognita adalah patogen yang menyebabkan penyakit lincat dan kerugian pada tembakau sampai 50\%, khususnya pada ketinggian 800-1100 m dpl (Purlani dan Rachman, 2000). Lahan pertanaman tembakau di daerah Temanggung dengan ketinggian tempat tersebut mempunyai kandungan bahan organik yang rendah (kurang dari $1 \%$ ) dan banyak mengandung Ralstonia solanacearum dan Meloidogyne incognita (Djajadi dan Murdiyati, 2000).

Upaya pengendalian kedua patogen tersebut telah banyak dilakukan diantaranya yaitu $R$. solanacearum dapat dikendalikan dengan rotasi tanaman, fumigasi, pengendalian nematoda dan gulma (Akiew and Trevorrow, 1994). Pengendalian $M$. incognita dilakukan dengan menggunakan nematisida karbofuran dan dazomet, dan menanam Tagetes spp. sebagai tanam rotasi (Dalmadiyo, 1996), menginokulasikan Pasteuria penetrans (Agrios, 2005; Ownley, 2002; Kerry, 2000), menggunakan campuran kotoran sapi dan urin (Abubakar et al., 2004). Upaya pengendalian kedua patogen tersebut belum memberikan hasil yang memuaskan karena salah satu kesulitannya mempunyai inang yang banyak, sehingga diperlukan upaya lain seperti pengendalian in vitro.

Upaya pengendalian Ralstonia solanacearum dan Meloidogyne incognita in vitro dapat dilakukan dengan menggunakan agensia pengendali hayati. Beberapa agensia pengendali hayati yang mempunyai kemampuan baik dalam pengendalian patogen lewat tanah yaitu Pseudomonas kelompok fluoresen (Kloepper, 1993), Bacillus spp., dan Streptomyces spp. (Cook and Baker, 1983). Bakteri-bakteri ini banyak ditemukan di rizosfer tanaman. Pseudomonas fluoresen yang diperoleh dari Mimosa invisa mampu menghambat pertumbuhan Ralstonia solanacearum in vitro dengan zona penghambatan bervariasi dari 2-15 $\mathrm{mm}$. Mekanisme penghambatan sebagian besar adalah bakterisidal dan hanya beberapa yang bersifat bakteriostatik (Arwiyanto, 1997). Isolat Bacillus spp. B46 cenderung mempunyai kemampuan yang sama sebagai pengendali Ralstonia solanacearum dan penyakit layu bakteri (Prihatiningsih et al., 2006). Streptomyces galbus R-5 endofitik efektif mengendalikan beberapa patogen karena mempunyai kemampuan hidup pada permukaan dan masuk jaringan daun sesudah kolonisasi jaringan inang, serta mendegradasi komponen dinding sel dengan enzim hidrolitik (selulase, pektinase, dan xilanase) (Minamiyama et al., 2003). Dalam penelitian ini, tiga genus bakteri yang digunakan yaitu bakteri yang diisolasi dari rizosfer cabai, kacang tanah, dan terung (Rahayu, 2005; Asfanudin, 2005; Haryono, 2005). Bakteri yang diperoleh disekitar tempat penelitian tersebut diharapkan mempunyai kemampuan yang baik sebagai antagonis penyakit lincat.

Penelitian bertujuan untuk mengkarakterisasi tiga genus bakteri yang diisolasi dari tiga rizosfer tanaman dan mengukur kemampuan antagonisnya dalam menekan penyakit lincat yang disebabkan oleh Ralstonia solanacearum and Meloidogyne incognita.

\section{METODE PENELITIAN}

Penelitian dilakukan di laboratorium Bakteriologi Tumbuhan dan Nematologi Tumbuhan dari bulan Januari sampai dengan Maret 2005.

Bahan penelitian yang digunakan terdiri atas medium untuk uji biokimia dan fisiologi bakteri antagonis, Buffer fosfat $\mathrm{pH} 7+0.1 \%$ pepton, benih tomat Varietas Ratna, R. solanacearum, tiga bakteri yang diisolasi dari rizosfer tanaman cabai, kacang tanah, dan terung, dan nematoda M. incognita. Alat-alat yang digunakan terdiri atas cawan petri, neraca analitis, vortex, drigalski spatula, sirakus, sentrifus, tabung sentrifus, tabung efendorf, mikropipet, lampu UV dengan panjang gelombang $365 \mathrm{~nm}$, dan autoklaf.

Bakteri rizosfer yang digunakan yaitu tiga genus bakteri yang diisolasi dari rizosfer cabai, kacang tanah, dan terung (Asfanudin, 2005; Haryono, 2005; Rahayu, 2005). 
Karakterisasi tiga genus bakteri yang diisolasi dari rizosfer tanaman

Karakterisasi bertujuan untuk mengetahui sifat biokimia dan fisiologi tiga bakteri. Metode yang digunakan untuk menguji sifat-sifat tersebut yaitu metode yang dikemukakan oleh Lelliot and Stead (1987). Sifat-sifat tersebut yaitu penggunaan senyawa karbon, nitrogen, perombakan makromolekul, uji reaksi gram, uji oksidase, uji katalase, pembentukan pigmen, lisin dekarboksilase, pertumbuhan pada berbagai suhu inkubasi, pertumbuhan suhu minimum dan maksimum, pertumbuhan pada $\mathrm{pH}$ medium, toleransi terhadap garam $(\mathrm{NaCl})$, aktivitas enzim, motilitas, dan pertumbuhan anaerobik.

Penekanan Ralstonia solanacearum dan Meloidogyne incognita in vitro

a. Penekanan Ralstonia solanacearum oleh antagonis dengan cara antibiosis in vitro. Penelitian menggunakan Rancangan Acak Lengkap, diulang 4 kali. Perlakuan terdiri atas $\mathrm{Ba} 4, \mathrm{Ba} 22$, Pf51, Pf83, S4, dan S7 in vitro terhadap Ralstonia solanacearum. Variabel yang diamati yaitu zona hambatan dan mekanisme penghambatannya. Pseudomonas kelompok fluoresen, Bacillus spp. dan Streptomyces spp. ditumbuhkan pada cawan petri berdiameter $9 \mathrm{~cm}$ berisi $10 \mathrm{~mL}$ medium YPGA (Yeast Peptone Glucose Agar) sebanyak satu isolat per cawan petri. Setelah masa inkubasi selama 48 jam pada suhu kamar, cawan petri dibalik dan pada tutupnya dituangi dengan kloroform sebanyak $0.5 \mathrm{~mL}$. Dua jam kemudian cawan petri dibalik kembali pada posisi semula. Pada permukaan medium tersebut dituangi dengan suspensi $0.2 \mathrm{~mL}$ Ralstonia solanacearum dalam $4 \mathrm{~mL} 0.6 \%$ agar air pada suhu $45^{\circ} \mathrm{C}$. Biakan diinkubasikan selama 24 jam pada suhu kamar, kemudian zona hambatan yang terbentuk diukur (Arwiyanto et al., 1996). Adanya zona hambatan menunjukkan bahwa antagonis tersebut mempunyai mekanisme penekanan secara antibiosis. Isolat yang mampu menghambat diuji sebanyak dua kali dengan medium dan metode yang sama.

Mekanisme bakteriostatik atau bakterisidal dideteksi dengan cara bagian zona hambatan diambil secukupnya dan dimasukkan dalam tabung reaksi yang berisi $5 \mathrm{ml}$ air pepton $0.5 \%$, kemudian digojok terus menerus selama 24 jam. Bakteriostatik ditunjukkan dengan air peptonnya keruh, sedangkan bakterisidal ditunjukkan dengan air peptonnya jernih.

b. Penekanan Meloidogyne incognita oleh antagonis. Penelitian menggunakan Rancangan Acak Lengkap, diulang 4 kali. Perlakuan terdiri atas Ba4, Ba22, Pf51, Pf83, S4, S7, dan kontrol. Variabel yang diamati yaitu persentase jumlah telur Meloidogyne incognita yang belum menetas, terdegradasi, dan menetas. Penyiapan ekstraksi telur Meloidogyne incognita dilakukan menurut cara Barker (1985). Penekanan Meloidogyne incognita oleh antagonis dilakukan dengan cara sebagai berikut: 1) akar tanaman tomat yang terinfeksi Meloidogyne incognita berumur 6-12 minggu dikumpulkan; 2) akar tersebut dimasukkan dalam $200 \mathrm{~mL}$ larutan NaOCL $0.5-1 \%$ dan digojok kuat selama 4 menit, kemudian disaring dengan menggunakan saringan berukuran 400 mesh dan 500 mesh untuk membebaskan telur; 3) residu $\mathrm{NaOCL}$ dihilangkan dengan cara menempatkan saringan berukuran 500 mesh dengan telur pada aliran air dingin selama beberapa menit; 4) sisasisa akar dibilas dengan air; 5) telur-telur yang masih muda, dikumpulkan dan digunakan sebagai inokulum; 6) Pada sirakus diberi masa telur Meloidogyne incognita dengan populasi tertentu dan kemudian diberi $0.75 \mathrm{~mL}$ suspensi antagonis dan pengamatan dilakukan setelah satu minggu.

\section{HASIL DAN PEMBAHASAN}

\section{Karakterisasi tiga genus bakteri yang diisolasi dari rizosfer tanaman}

Hasil karakterisasi menunjukkan bahwa tiga genus bakteri yang diisolasi dari rizosfer tanaman yaitu masing-masing (Pf51 dan Pf83), (Ba4 dan Ba22), dan (S4 dan S7) mampu memanfaatkan senyawa karbon dan nitrogen, dan mendegradasi makromolekul. Uji gram Pf51 dan Pf83 bersifat negatif, sedangkan Ba4, Ba22, S4, dan S7 bersifat positif; uji oksidase, katalase, dan $\mathrm{O} / \mathrm{F}$ keenam bakteri tersebut bersifat positif dan mampu tumbuh pada medium yang mengandung kitin dan pektin. 
Pf51 dan Pf83 menghasilkan levan, pigmen fluorecein, tumbuh pada suhu $4{ }^{\circ} \mathrm{C}$ dan $\mathrm{pH} 5,0$, $6,0,7,0,8,5,10$, dan toleran terhadap $\mathrm{NaCl}(0.5$, 0.75, 1, 1.5, dan 2\%). Ba4 dan Ba22 tumbuh pada suhu $4,18,20,25,45$ dan $65^{\circ} \mathrm{C}$, toleran terhadap $\mathrm{NaCl} 1,2,3,4,5,6$, dan 7\%. S4 dan S7 tumbuh pada suhu 4,1037 , dan $45^{\circ} \mathrm{C}$, serta $\mathrm{pH} 4.3$, toleran terhadap $\mathrm{NaCl} 7$ dan $13 \%$ (Tabel 1).

Tabel 1. Sifat biokimia dan fisiologi tiga genus bakteri (Pf, Ba, dan S) yang diisolasi dari rizosfer tanaman

\begin{tabular}{|c|c|c|c|c|c|c|c|}
\hline \multirow{2}{*}{ No. } & \multirow{2}{*}{ Pengujian } & \multicolumn{6}{|c|}{ Isolat } \\
\hline & & Pf51 & Pf 83 & $\mathrm{Ba4}$ & $\mathrm{Ba} 22$ & $\mathrm{S4}$ & 57 \\
\hline \multirow[t]{12}{*}{1.} & Penggunaan senyawa karbon: & & & & & & \\
\hline & a. Glukosa & + & + & + & + & + & + \\
\hline & b. Fruktosa & + & + & + & + & + & + \\
\hline & c. Maltosa & + & + & + & + & + & + \\
\hline & d. Selobiosa & + & + & + & + & + & + \\
\hline & e. Laktosa & + & + & - & - & - & - \\
\hline & f. Sukrosa & + & + & + & + & + & + \\
\hline & g. Trehalosa & + & + & + & + & + & + \\
\hline & h. Sorbitol & + & + & - & - & - & - \\
\hline & i. Manitol & + & + & - & - & - & - \\
\hline & j. Myo inositol & + & + & + & + & - & - \\
\hline & k. Penggunaan sitrat & $\mathrm{T}$ & $\mathrm{T}$ & + & + & $\mathrm{T}$ & $\mathrm{T}$ \\
\hline \multirow[t]{9}{*}{2 . } & Penggunaan senyawa nitrogen: & & & & & & \\
\hline & a. Uji reduksi nitrat & - & + & + & + & $\mathrm{T}$ & $\mathrm{T}$ \\
\hline & b. Aktivitas urease & + & + & $\mathrm{T}$ & $\mathrm{T}$ & $\mathrm{T}$ & $\mathrm{T}$ \\
\hline & c. $\mathrm{Uji}$ indol & + & - & - & - & - & - \\
\hline & d. Denitrifikasi & - & - & $\mathrm{T}$ & $\mathrm{T}$ & $\mathrm{T}$ & $\mathrm{T}$ \\
\hline & e. Histidin & $\mathrm{T}$ & $\mathrm{T}$ & $\mathrm{T}$ & $\mathrm{T}$ & + & + \\
\hline & f. Prolin & $\mathrm{T}$ & $\mathrm{T}$ & $\mathrm{T}$ & $\mathrm{T}$ & + & + \\
\hline & g. Sistein & $\mathrm{T}$ & $\mathrm{T}$ & $\mathrm{T}$ & $\mathrm{T}$ & + & + \\
\hline & h. Hidrolisis arginin & + & + & $\mathrm{T}$ & $\mathrm{T}$ & $\mathrm{T}$ & $\mathrm{T}$ \\
\hline \multirow[t]{6}{*}{3.} & Degradasi makromolekul: & & & & & & \\
\hline & a. Hidrolisis gelatin & - & - & - & - & + & + \\
\hline & b. Hidrolisis pati & - & - & + & + & + & + \\
\hline & c. Hidrolisis tween 80 (aktivitas lipolitik) & - & - & + & + & + & + \\
\hline & d. Eskulin & $\mathrm{T}$ & $\mathrm{T}$ & $\mathrm{T}$ & $\mathrm{T}$ & + & + \\
\hline & e. Reaksi kuning telur & $\mathrm{T}$ & $\mathrm{T}$ & + & + & + & + \\
\hline \multirow[t]{10}{*}{4.} & Lain-1ain: & & & & & & \\
\hline & a. Uji Reaksi Gram & - & - & + & + & + & + \\
\hline & b. Uji Oksidase & + & + & + & + & + & + \\
\hline & c. Uji katalase & + & + & + & + & + & + \\
\hline & d. $\mathrm{Uji}_{\mathrm{ji}} \mathrm{O} / \mathrm{F}$ & + & + & + & + & + & + \\
\hline & e. Produksi Levan & + & + & $\mathrm{T}$ & $\mathrm{T}$ & $\mathrm{T}$ & $\mathrm{T}$ \\
\hline & $\begin{array}{l}\text { f. Uji Voges Proskauer (VP) dan } \\
\text { Methyl Red (MR) }\end{array}$ & - & - & - & - & $\mathrm{T}$ & $\mathrm{T}$ \\
\hline & $\begin{array}{l}\text { g. Pembentukan pigmen pada medium } \\
\text { King's A }\end{array}$ & - & - & $\mathrm{T}$ & $\mathrm{T}$ & $\mathrm{T}$ & $\mathrm{T}$ \\
\hline & $\begin{array}{l}\text { h. Pembentukan pigmen pada medium } \\
\text { King's B }\end{array}$ & + & + & $\mathrm{T}$ & $\mathrm{T}$ & $\mathrm{T}$ & $\mathrm{T}$ \\
\hline & i. Lisin dekarboksilase & - & - & $\mathrm{T}$ & $\mathrm{T}$ & $\mathrm{T}$ & $\mathrm{T}$ \\
\hline
\end{tabular}

+: reaksi positif atau ada pertumbuhan bakteri; -: reaksi negatif atau tidak ada pertumbuhan bakteri; $\mathrm{T}$ : tidak dilakukan 
Tabel 1 (lanjutan)

\begin{tabular}{|c|c|c|c|c|c|c|}
\hline \multirow{2}{*}{ Pengujian } & \multicolumn{6}{|c|}{ Isolat } \\
\hline & Pf51 & Pf 83 & $\mathrm{Ba} 4$ & $\mathrm{Ba} 22$ & $\mathrm{~S} 4$ & 57 \\
\hline \multicolumn{7}{|l|}{ j. Pertumbuhan pada suhu } \\
\hline j. $1.4^{\circ} \mathrm{C}$ & + & + & $\mathrm{T}$ & $\mathrm{T}$ & + & + \\
\hline j. $2.10^{\circ} \mathrm{C}$ & $\mathrm{T}$ & $\mathrm{T}$ & $\mathrm{T}$ & $\mathrm{T}$ & + & + \\
\hline j. $3.37^{\circ} \mathrm{C}$ & $\mathrm{T}$ & $\mathrm{T}$ & $\mathrm{T}$ & $\mathrm{T}$ & + & + \\
\hline j. $4.41^{\circ} \mathrm{C}$ & - & - & $\mathrm{T}$ & $\mathrm{T}$ & $\mathrm{T}$ & $\mathrm{T}$ \\
\hline j. $5.45^{\circ} \mathrm{C}$ & $\mathrm{T}$ & $\mathrm{T}$ & + & + & + & + \\
\hline j. $6.65^{\circ} \mathrm{C}$ & $\mathrm{T}$ & $\mathrm{T}$ & + & + & $\mathrm{T}$ & $\mathrm{T}$ \\
\hline \multicolumn{7}{|l|}{$\begin{array}{l}\text { k. Pertumbuhan suhu minimum dan } \\
\text { maksimum }\end{array}$} \\
\hline k.1. $4^{\circ} \mathrm{C}$ (39 hari) & $\mathrm{T}$ & $\mathrm{T}$ & + & + & $\mathrm{T}$ & $\mathrm{T}$ \\
\hline k.2. Di bawah $20^{\circ} \mathrm{C} / 18^{\circ} \mathrm{C}$ (24 hari) & $\mathrm{T}$ & $\mathrm{T}$ & + & + & $\mathrm{T}$ & $\mathrm{T}$ \\
\hline k. $3.20^{\circ} \mathrm{C}(14$ har 1$)$ & $\mathrm{T}$ & $\mathrm{T}$ & + & + & $\mathrm{T}$ & $\mathrm{T}$ \\
\hline k.4. $25^{\circ} \mathrm{C}(14$ har 1$)$ & $\mathrm{T}$ & $\mathrm{T}$ & + & + & $\mathrm{T}$ & $\mathrm{T}$ \\
\hline k. $5.45^{\circ} \mathrm{C}(5$ hari $)$ & $\mathrm{T}$ & $\mathrm{T}$ & + & + & $\mathrm{T}$ & $\mathrm{T}$ \\
\hline k. $6.65^{\circ} \mathrm{C}(2$ hari $)$ & $\mathrm{T}$ & $\mathrm{T}$ & + & + & $\mathrm{T}$ & $\mathrm{T}$ \\
\hline \multicolumn{7}{|l|}{ 1. Pertumbuhan pada $\mathrm{pH}$} \\
\hline 1.1. $\mathrm{pH} 4$ & - & - & $\mathrm{T}$ & $\mathrm{T}$ & $\mathrm{T}$ & $\mathrm{T}$ \\
\hline 1.2. $\mathrm{pH} 4.3$ & $\mathrm{~T}$ & $\mathrm{~T}$ & $\mathrm{~T}$ & $\mathrm{~T}$ & + & + \\
\hline 1.3. $\mathrm{pH} 4.5$ & - & - & $\mathrm{T}$ & $\mathrm{T}$ & $\mathrm{T}$ & $\mathrm{T}$ \\
\hline 1.4. $\mathrm{pH} 5$ & + & + & $\mathrm{T}$ & $\mathrm{T}$ & $\mathrm{T}$ & $\mathrm{T}$ \\
\hline 1.5. $\mathrm{pH} 6$ & + & + & $\mathrm{T}$ & $\mathrm{T}$ & $\mathrm{T}$ & $\mathrm{T}$ \\
\hline 1.6. $\mathrm{pH} 7$ & + & + & $\mathrm{T}$ & $\mathrm{T}$ & $\mathrm{T}$ & $\mathrm{T}$ \\
\hline 1.7. $\mathrm{pH} 8.5$ & + & + & $\mathrm{T}$ & $\mathrm{T}$ & $\mathrm{T}$ & $\mathrm{T}$ \\
\hline 1.8. $\mathrm{pH} 10$ & + & + & $\mathrm{T}$ & $\mathrm{T}$ & $\mathrm{T}$ & $\mathrm{T}$ \\
\hline
\end{tabular}

+: reaksi positif atau ada pertumbuhan bakteri; -: reaksi negatif atau tidak ada pertumbuhan bakteri; T: tidak dilakukan

Tabel 2. Rata-rata zona hambatan oleh antagonis terhadap Ralstonia solanacearum

\begin{tabular}{lccl}
\hline \hline \multirow{2}{*}{ Perlakuan } & \multicolumn{2}{c}{ Zona hambatan $(\mathrm{mm})$} & $\begin{array}{c}\text { Mekanisme } \\
\text { penghambatan }\end{array}$ \\
\cline { 2 - 4 } & Percobaan pertama & Percobaan kedua & Bakteriostatik \\
\hline Ba4 + Rs & $14.1 \mathrm{a}$ & $12.9 \mathrm{ab}$ & Bakteriostatik \\
Ba22 + Rs & $2.3 \mathrm{c}$ & $3.3 \mathrm{c}$ & Bakteriostatik \\
Pf51 + Rs & $0.5 \mathrm{~d}$ & $2.4 \mathrm{c}$ & Bakteriostatik \\
Pf83 + Rs & $11.0 \mathrm{~b}$ & $14.3 \mathrm{a}$ & Bakteriostatik \\
S4 + Rs & $15.3 \mathrm{a}$ & $10.5 \mathrm{~b}$ & Bakteriostatik \\
S7 + Rs & $9.8 \mathrm{~b}$ & $12.6 \mathrm{~b}$ & \\
\hline
\end{tabular}

Angka yang diikuti huruf yang sama dalam kolom yang sama tidak berbeda nyata berdasarkan Uji Jarak Berganda Duncan pada taraf $5 \%$ )

Kemampuan tersebut menunjukkan bahwa enam bakteri tersebut sangat baik digunakan untuk produksi biomassa antagonis yang sangat diperlukan untuk pengendalian hayati patogen lewat tanah. Hal ini berarti ke enam bakteri tersebut mempunyai spektrum yang luas. Salah satu persyaratan agensia pengendali hayati yang baik untuk digunakan mengendalikan patogen lewat tanah yaitu mempunyai spektrum yang luas (Cook and Baker, 1996). 
Tabel 3. Rata-rata persentase jumlah telur Meloidogyne incognita yang belum menetas, jumlah telurMeloidogyne incognita yang terdegradasi, dan jumlah telur Meloidogyne incognita yang menetas yang diperlakukan dengan antagonis

\begin{tabular}{cccc}
\hline \hline Perlakuan & $\begin{array}{c}\text { Persentase jumlah } \\
\text { telur Meloidogme } \\
\text { incognita yang belum } \\
\text { menetas }\end{array}$ & $\begin{array}{c}\text { Persentase jumlah } \\
\text { telur Meloidogme } \\
\text { incognita yang } \\
\text { terdegradasi }\end{array}$ & $\begin{array}{c}\text { Persentase jumlah } \\
\text { telur Meloidogme } \\
\text { incognita yang } \\
\text { menetas }\end{array}$ \\
\hline Ba4 & $74.68 \mathrm{a}$ & $26.51 \mathrm{e}$ & $0.00 \mathrm{c}$ \\
Ba22 & $53.43 \mathrm{~b}$ & $46.57 \mathrm{~d}$ & $0.00 \mathrm{c}$ \\
Pf51 & $24.26 \mathrm{~cd}$ & $75.75 \mathrm{bc}$ & $0.00 \mathrm{c}$ \\
Pf83 & $32.38 \mathrm{c}$ & $67.62 \mathrm{c}$ & $0.00 \mathrm{c}$ \\
S4 & $6.93 \mathrm{e}$ & $93.07 \mathrm{a}$ & $0.00 \mathrm{c}$ \\
S7 & $8.47 \mathrm{e}$ & $86.77 \mathrm{ab}$ & $3.89 \mathrm{~b}$ \\
Kontrol & $10.13 \mathrm{de}$ & $0.00 \mathrm{f}$ & $89.87 \mathrm{a}$ \\
\hline Ankatang
\end{tabular}

Angka yang diikuti huruf yang sama dalam kolom yang sama tidak berbeda nyata berdasarkan Uji Jarak Berganda Duncan pada taraf $5 \%$ )

Penekanan Ralstonia solanacearum dan Meloidogyne incognita in vitro

Hasil percobaan penekanan antagonis (Ba4, Ba22, Pf51, Pf83, S4, dan S7) terhadap Ralstonia solanacearum berbeda nyata baik pada percobaan pertama atau kedua. Perlakuan antagonis yang mempunyai kemampuan baik menekan Ralstonia solanacearum pada percobaan pertama dan kedua masing-masing S4 dan Pf83, sedangkan S4 terhadap Meloidogyne incognita. Semua antagonis yang digunakan dalam menekan Ralstonia solanacearum mempunyai mekanisme penghambatan secara bakteriostatik (Tabel 2 dan 3).

Pseudomonas kelompok fluoresen dan Bacillus spp. mempunyai kemampuan yang baik dalam menekan Ralstonia solanacearum in vitro (Arwiyanto, 1997). Kemampuan antagonis dalam menekan patogen in vitro karena pada kondisi laboratorium, antagonis hanya berhadapan dengan patogen dan ada dalam lingkungan kaya nutrisi, sehingga mampu memunculkan kemampuannya dalam menghambat patogen.

Enam antagonis yang dicoba berbeda nyata dalam kemampuannya menekan Meloidogyne incognita yang ditunjukkan dengan persentase jumlah telur yang belum menetas, jumlah telur yang terdegradasi dan menetas dibandingkan dengan kontrol. Di antara antagonis yang dicoba, antagonis $\mathrm{S} 4$ mempunyai kemampuan paling baik dalam menekan Meloidogyne incognita, diikuti antagonis S7, Pf51, Pf83, Ba22, dan Ba4 (Tabel
3). Kemampuan tersebut karena ke enam antagonis (Pf51, Pf83, Ba22, Ba4, S4, dan S7) mampu tumbuh pada medium yang mengandung kitin dan antagonis (Ba22, Ba4, S4, dan S7) mampu tumbuh pada medium yang mengandung kuning telur (Tabel 1). Kitin dan kuning telur adalah penyusun dari telur Meloidogyne incognita, sehingga menyebabkan antagonis tersebut mampu mendegradasi telur Meloidogyne incognita. Selain itu, Streptomyces spp. menghasilkan antibiotik yang berspektrum luas yaitu metabolit sekunder (alnumisin, phthoxazolin $A$ dan $B-D$ ), antibiotik polyene, vinilamisin, dan geldamisin (Shimizu et al., 2000).

Antagonis Pseudomonas spp., Bacillus spp., dan Streptomyces spp. mempunyai pengaruh langsung pada telur dan mobilitas nematoda (Kerry, 2000), dan kemampuan menekan nematoda dengan memproduksi metabolit yang mengurangi menetasnya telur dan aktivitas nematoda (Siddiqui and Shaukat, 2002).

\section{KESIMPULAN}

Keenam bakteri tersebut mampu memanfaatkan beberapa senyawa karbon dan nitrogen, mendegradasi makromolekul, mampu tumbuh pada berbagai suhu dan kandungan garam, dan tumbuh pada medium yang mengandung kitin dan pektin.

Isolat bakteri yang diisolasi dari rizosfer lombok (Pf51, Ba4, Ba22), kacang tanah (Pf83), 
dan terung (S4 dan S7) yang dikarakterisasi termasuk dalam Pseudomonas kelompok fluoresen (Pf51 dan Pf 83), Bacillus spp. (Ba4 dan Ba22), dan Streptomyces spp. (S4 dan S7).

Keenam isolat bakteri mempunyai kemampuan antagonis.

Isolat bakteri yang paling baik dalam menekan Ralstonia solanacearum dan Meloidogyne incognita adalah Streptomyces spp. (S4).

Isolat bakteri yang paling baik menekan $R$. solanacearum dengan cara antibiosis dan mekanisme penghambatan secara bakteriostatik adalah S4.

\section{UCAPAN TERIMA KASIH}

Penulis mengucapkan terima kasih kepada pemberi dana, Dekan Fakultas Pertanian, Kepala Laboratorium Bakteriologi Tumbuhan, Kepala Laboratorium Nematologi Tumbuhan, dan Kepala Laboratorium Tanah UGM atas fasilitas yang diberikan selama penelitian.

\section{DAFTAR PUSTAKA}

Abubakar, U., T. Adamu, and S.B. Manga. 2004. Control of Meloidogyne incognita (kofoid and white) Chitwood (root-knot nematode) of Lycopersicon esculentus (Tomato) using cowdung and urine. African Journal of Biotechnology 3: 379-381.

Agrios, G.N. 2005. Plant Pathology. 5th ed. ELSEVIER Academic Press, New York.

Akiew, E. and P.R. Trevorrow. 1994. Management of Bacterial Wilt of Tobacco. In: Hayward, A.C. and G.I. Hartman (Eds). p:179-198 Bacterial Wilt The Disease and Its Causative Agent, Pseudomonas solanacearum. CAB International, Taiwan.

Arwiyanto, T. 1997. Pengendalian Hayati Penyakit Layu Bakteri Tembakau:1. Isolasi Bakteri Antagonis. Jurnal Perlindungan Tanaman Indonesia 3(1): 54-60.

Arwiyanto, T., Sudarmadi, and I. Hartana. 1996. Deteksi strain Pseudomonas solanacearum penghasil bakteriosin. Jurnal Perlindungan Tanaman Indonesia. 2(2): 61-65.

Arwiyanto, T. 1997. Pengendalian hayati penyakit layu bakteri tembakau:1. isolasi bakteri antagonis. Jurnal Perlindungan Tanaman Indonesia 3: 54-60.

Asfanudin, K. 2005. Kajian pengendalian penyakit lincat tembakau temanggung menggunakan Bacillus spp. Skripsi. Fakultas Pertanian UGM, Yogyakarta.

Barker, K.R. 1985. Nematode Extraction and Bioassays. In: K.R. Barker, C.C. Carter, \& J.N. Sasser (Eds.) p. 19-35. An Advanced Treatise on Meloidogyne Volume II: Methodology. Printed by North Carolina State University Graphics.

Cook, R.J. and K.F. Baker. 1996. The Nature and Practice of Biological Control of Plant Pathogens. The APS St. Paul, Minnesota.

Cook, R.J. and K.F. Baker. 1983. The Nature and Practice of Biological Control of Plant Pathogens. The APS St. Paul, Minnesota.

Dalmadiyo, G. 1996. Tembakau Temanggung dan Temanggungan. Balitas Malang.

Djajadi dan A.S. Murdiyati. 2000. Hara dan Pemupukan Tembakau Temanggung. Balai Penelitian Tembakau dan Tanaman Serat, Malang.

Haryono, K. 2005. Kajian pengendalian penyakit lincat tembakau temanggung menggunakan Streptomyces spp. Skripsi. Fakultas Pertanian UGM, Yogyakarta. (Tidak dipublikasikan)

Kerry, B.R. 2000. Rhizosphere Interaction and the Exploitation of Microbial Agents for the Biological Control of Plant-Parasitic Nematodes. Annu. Rev. Phytopathology 38: 423-441.

Kloepper, J.W. 1993. Plant Growth-Promoting Rhizobacteria as Biological Control Agents. In: F.B. Mettting (ed.) p. 255-274. Soil Microbial Ecology. Marcel Dekker, Inc, New York.

Lelliot, R.A. and D.E. Stead. 1987. Methods for the Diagnosis of Bacterial Diseases of Plants. 
British Society for Plant Pathology by Blackwell Scientific Publications, Melbourne. Minamiyama, H., M. Shimizu, H. Kunoh, T. Furumai, Y. Igarasi, H. Onaka, and R. Yoshida. 2003. Multiplication of isolate R-5 Streptomyces galbus on rhododendron leaves and its production of cell walldegrading enzymes. Journal Gen. Plant Pathology 69: 65-70.

Ownly, B.H. 2002. Biological Control of Tobacco Diseases. p: 111-130. In. Biological Control of Crop Diseases by Gnanamanickam, S.S. Marcel Dekker, New York.

Prihatiningsih, N., Soedarmono, T. Arwiyanto, dan B. Hadisutrisno. 2006. Pengendalian hayati penyakit layu bakteri kentang dengan Bacillus spp.: 1. Eksplorasi dan Pengujian in vitro dan rumah plastik. Agrosains 8: 27-31.

Purlani, E. dan A. Rachman. 2000. Budidaya Tembakau Temanggung. Balai Penelitian Tembakau dan Tanaman Serat, Malang.

Rahayu, F.Y. 2005. Kajian pengendalian penyakit lincat tembakau temanggung menggunakan pseudomonad fluoresen. Skripsi. Fakultas Pertanian UGM, Yogyakarta. (Tidak dipublikasikan)

Shimizu, M., Y. Nakagawa, Y. Sato, T. Furamai, Y. Igarashi, H. Onaka, R. Yoshida, and H. Kunoh. 2000. Studies on endophytic actinomycetes (I) Streptomyces sp. isolated from rhododendron and its antifungal activity. Journal Gen. Plant Pathology. 66: 360-366. 